\title{
What If the 'Anthropocene' Is Not Formalized as a New Geological Series/Epoch?
}

\author{
Valentí Rull $\mathbb{D}$ \\ Institute of Earth Sciences Jaume Almera, ICTJA, CSIC, C/ Solé i Sabarís, s/n, 08028 Barcelona, Spain; \\ vrull@ictja.csic.es
}

Received: 15 October 2018; Accepted: 16 October 2018; Published: 19 October 2018

\begin{abstract}
In the coming years, the Anthropocene Working Group (AWG) will submit its proposal on the 'Anthropocene' to the Subcommission of Quaternary Stratigraphy (SQS) and the International Commission on Stratigraphy (ICS) for approval. If approved, the proposal will be sent to the Executive Committee of the International Union of Geological Sciences (IUGS) for ratification. If the proposal is approved and ratified, then the 'Anthropocene' will be formalized. Currently, the 'Anthropocene' is a broadly used term and concept in a wide range of scientific and non-scientific situations, and, for many, the official acceptance of this term is only a matter of time. However, the AWG proposal, in its present state, seems to not fully meet the requirements for a new chronostratigraphic unit. This essay asks what could happen if the current 'Anthropocene' proposal is not formalized by the ICS/IUGS. The possible stratigraphic alternatives are evaluated on the basis of the more recent literature and the personal opinions of distinguished AWG, SQS, and ICS members. The eventual impact on environmental sciences and on non-scientific sectors, where the 'Anthropocene' seems already firmly rooted and de facto accepted as a new geological epoch, are also discussed. This essay is intended as the editorial introduction to a Quaternary special issue on the topic.
\end{abstract}

Keywords: Anthropocene; human impact; chronostratigraphy; geochronology; International Chronostratigraphic Chart; Geological Time Scale; chronostratigraphic units; series; epoch; formalization

\section{Current Status of the 'Anthropocene'}

In spite of its rather common usage in a wide array of scientific and non-scientific environments, the 'Anthropocene' is an informal term (this is why the quotation marks) whose formalization process is in a still very incipient phase. The first step is to assemble a proposal to be submitted to the Subcommission of Quaternary Stratigraphy (SQS) and then to its parent body, the International Commission on Stratigraphy (ICS), for approval. If approved, the proposal can or cannot be ratified by the Executive Committee of the International Union of Geological Sciences (IUGS). If ratified, the new unit can be incorporated to the International Chronostratigraphic Chart (ICC), which is the international stratigraphic reference and is the basis for the Geological Time Scale (GTS), one of the great achievements of humanity, comparable to the periodic table of elements [1]. For a new chronostratigraphic unit to be defined, it is necessary first to recognize and date its lower boundary on a particular strata sequence (the type section or stratotype) from a particular locality (the type locality) and to identify the particular strata features (the stratigraphic markers) that characterize such a unit and differentiate it from the underlying one. Once identified, the position of the stratigraphic marker in this locality becomes the Global boundary Stratotype Section and Point (GSSP) of the eventual new unit, which is required for a proposal to be submitted to the ICS. The proposed unit should be global and synchronous, that is, it should be recognizable worldwide and its lower boundary should have the same age everywhere [2]. 
Since 2009, the Anthropocene Working Group (AWG) has been working on a proposal about the 'Anthropocene' as a new series/epoch of the ICC following the Holocene. Details on the composition and activities of this task group can be seen in its website (http:/ / quaternary.stratigraphy.org/workinggroups / anthropocene). To date, the AWG has preliminarily established the age for the beginning of the 'Anthropocene' and the potential stratigraphic markers and now is working on characterizing potential stratotypes for the corresponding GSSP [3]. In its present state, the proposal places the onset of the 'Anthropocene' epoch at the mid-20th century ( 1950), coinciding with the Great Acceleration, and suggests that the plutonium $(\mathrm{Pu})$ fallout, originated by the first nuclear explosions, could be the best stratigraphic marker [4]. According to the latest publications on the subject, the AWG estimates to have the proposal ready for submission by 2019 or 2020 [4]. However, the AWG Convenor, Jan Zalasiewicz (University of Leicester, UK), in a recent communication [5], told the author of this paper that the project is very big and the final proposal may actually take more time.

The approval process is complex and time consuming and it involves several organization levels within the ICS, structured in a hierarchical manner. Proposals should be submitted first to the corresponding subcommission, in this case, the Subcommission on Quaternary Stratigraphy (SQS) and, if approved, they move forward to the ICS. Approval by these two instances requires supermajority, as expressed in the positive votes of $60 \%$ or more of their respective members after detailed analysis and discussion of the topic, which may involve a significant amount of time. Proposals that fail to achieve supermajority may be returned to the AWG for eventual reformulation, with the corresponding additional time and effort. If finally approved by the ICS, the proposal is submitted to the Executive Committee of the International IUGS for ratification, which is not automatic either and it requires further scientific evaluation [6,7]. More detailed information on the official rules and the approval process can be found in the ICS website (http:/ / www.stratigraphy.org).

The AWG is very active in the dissemination of its progress on the definition and characterization of the 'Anthropocene', which are frequently published in books [8] and journals, including high-impact multidisciplinary ones [9]. The AWG advances are commented on by other scholars, who agree or disagree with their propositions. Sometimes, the commentaries come from geologists who are members of the highest ICS and/or IUGS hierarchical levels $[6,7,10,11]$, which could be useful to appreciate how the proposal is received at these decision stages. The latest publications of this type may suggest that, in its present form - that is, the mid-20th century as the 'Anthropocene' onset and the $\mathrm{Pu}$ fallout as the stratigraphic marker-the current AWG proposal might not be approved. Therefore, contrary to many expectations, the formalization of the 'Anthropocene' does not seem to be merely a matter of time. The critiques emphasize some procedural flaws-notably that the 'Anthropocene' does not derive from a stratigraphic concern but from purely environmental considerations-and stratigraphic weaknesses-for example, the lack of a physical stratigraphic basis to represent an eventual 'Anthropocene' starting at $1950-$, as well as the fact that the interest on the formalization of the 'Anthropocene' is not genuinely scientific, but it has political (environmental) motivations $[10,11]$ or is a phenomenon of pop culture [12]. The AWG members have responded to these critiques but the basic elements of their proposal have been maintained $[13,14]$. The detailed arguments from both sides are beyond the aims of this paper, which is focused on what would happen if the AWG proposal is finally rejected by the ICS/IUGS, a possibility that is rarely addressed.

\section{Stratigraphic Alternatives}

First of all, it should be stressed that the AWG can still change or modify its current interim position. There are internal discussions to do so, as some believe that the current proposal ignores previous centuries or millennia of human interference in the Earth System [15-17]. For example, Erle Ellis (University of Maryland-Baltimore County, USA), an environmental scientist member of the AWG, argues that: "Evidence for human transformation of Earth's functioning as a system is robust and superabundant-the data speak for themselves, from atmosphere and climate to biosphere and lithosphere, human societies have emerged as a force of nature that is shaping the trajectory of 
this planet. While a formal Anthropocene epoch might simplify recognition of this transformation, the chronostratigraphic requirement for dividing Earth history into discrete intervals that begin globally at a specific instant in time, will obscure rather than clarify the heterogeneous and diachronous nature of the human social-ecological processes that have emerged to transform this planet" [18]. The problem is that, according to the current stratigraphic rules, a diachronic boundary is not acceptable for characterizing a chronostratigraphic unit. But, as Jan Zalasiewicz points out, "the 'Anthropocene' is not being defined as the onset of human influence on Earth"; in other words, 'Anthropocene' does not mean 'anthropogenic' [19].

There is also the possibility of defining a stratigraphic unit different from an epoch. For example, Philip Gibbard (University of Cambridge, UK), the ICS Secretary-General, mentioned two other possibilities [20]: (i) to define an event or episode or (ii) to define a subdivision of the Late Holocene subseries/subepoch, after the Meghalayan Stage, either as a stage/age or a chron. Gibbard also suggested the AWG to propose the definition of a GSSA (Global Standard Stratigraphic Age), instead of a GSSP for the lower boundary. These possibilities would avoid conflict with a number of SQS members, especially those from the Holocene community, who are reluctant to accept that the Holocene ended with the Great Acceleration [20]. Any of the above options require a term different from 'Anthropocene', as the termination '-cene' is reserved for the Cenozoic series/epochs [21]. The AWG is reluctant to accept these alternatives, as they imply the stratigraphic downgrading of the 'Anthropocene' to a subunit of the Holocene. For example, Martin Head (Brock University, Canada), the SQS Chair and member of the AWG, argues that the natural Holocene variability has already been surpassed, and, therefore, it would not make sense to define the 'Anthropocene' as a subunit of the Holocene [22]. Jan Zalasiewicz adds that " ... changes associated with the Anthropocene are of greater magnitude that those associated with current subdivisions of the Holocene, and in many instances are greater than those associated with the Pleistocene-Holocene boundary ... " [19].

In addition, an eventual stratigraphic downgrading of the 'Anthropocene' to a Holocene subunit would challenge a fundamental aspect of the current AWG interim proposal as is that the 'Anthropocene' should be formalized as a new geological series/epoch [4], which implies that the Holocene has terminated. This also challenges the conviction of many AWG members who defend that the 'Anthropocene' represents a new state of the biosphere after the microbian stage (of approximately three-billion years duration, since the origin of life until the end of the Precambrian) and the metazoan stage (since the origin of the metazoans, approximately 0.7 billion years ago to the present) [23]. Merely a subdivision of the Late Holocene would hardly represent such telluric revolution. Perhaps a series/epoch would be equally insufficient to account for a deep transformation like this, which opens another possibility, as is the upgrading of the eventual chronostratigraphic unit based on human footprint to the rank of an era [24], such as the 'Anthropozoic', as proposed by Stoppani about one century and a half ago [25]. Lucy Edwards (US Geological Survey), a member of the ICS Subcommission of Stratigraphic Classification, also expresses her surprise that "... the AWG doesn't discuss system/period or erathem/era status for the Anthropocene" [26]. The AWG has considered and discussed both downgrading and upgrading options [19], but the result of the latest internal voting was that the 'Anthropocene' should be proposed as a series/epoch [4]. Still, another option, after eventual rejection, would be to abandon the venture of defining a new stratigraphic unit based on the human footprint on Earth. Neither the ICS nor the IUGS have responsibility for this (although they can recommend that course of action), only the SQS or the AWG can decide about resubmitting or not a new proposal [20].

The author asked Jan Zalasiewicz about the possibility of an eventual plan B if the proposal is not approved and/or ratified, and he responded that: "The plan A is always to do the best and most honest scientific job possible, and then see what happens. The long-term aim (whether the case is accepted/ratified or not) is to build up the science base so that the term can (whether formal or not) be more effectively used and understood, at least in a geological/Earth System science sense" [5]. Therefore, it seems clear that the AWG has no plan B and it remains attached to its original idea 
and, therefore, the above-mentioned upgrading or downgrading options will not be considered. Some members of the IUGS Executive were also approached by the author for opinion but they did not answer or declined to comment the issue, arguing that, as members of the organization responsible for the final decision, they are not free to express their personal opinion on the subject, at this stage. The only general comment from a IUGS member who will remain anonymous was: " . . the issue of the Anthropocene is getting out of hand: too much media hype, too little scientific reasoning". But, Martin Head argues that " ... there has been an abundance of scientific reasoning. What has actually been lacking is evidence from the sedimentary record, but this is now finally being addressed" [22].

\section{Beyond Geology}

Strictly speaking, if the term 'Anthropocene' is not formalized, it should not be used, but, in the words of Philip Gibbard [20], the ICS is not a police force and cannot stop people using terms. In addition, the term is firmly rooted in many professional and public environments-even in renowned dictionaries (Oxford, Cambridge, Collins, Merriam-Webster, MacMillan)—and, according to Ruddiman et al. [27], the term 'Anthropocene' is here to stay. Lucy Edwards believes that the term 'Anthropocene': " . . will be used in a cultural sense to indicate and call attention to the fact that humankind significantly influences the global environment. It will represent a holistic concept and it may have different start times in different places in the world. It may depend on different features or environmental effects. Deposits of anthropogenic origin will be considered Anthropocene deposits. The Anthropocene can easily be depicted on the formal Geologic Time Scale but will not be a formal unit of it. Some people may consider the Anthropocene to be an informal unit of geologic time. Others may not consider it a time unit at all" [11]. Jan Zalasiewicz adds that "... there are informal but widely used and widely understood time terms, most notably 'Precambrian' and 'Tertiary'; the important thing is that these, though, informal, are clearly defined and clearly distinct episodes of history. If the Anthropocene is not to be formally defined in the near future, it still represents a clearly distinct phenomenon quite separate in many respects from the bulk of the Holocene, and this seems to warrant having its own name or label for ease of communication" [19].

Due to its environmental connotations-we should not forget that the term was coined by an environmental chemist (Paul Crutzen) and an ecologist (Eugene Stoermer) on the basis of environmental criteria [28] — this term has been especially successful in the fields of ecology, conservation, and environmental sciences, in general, where it has been de facto adopted by many as a new geological unit of varied ranks (epoch, era, stage, period), without waiting for its eventual formalization. Currently, there are three scientific journals with the word Anthropocene (without quotes) in their titles, namely The Anthropocene (Elsevier), The Anthropocene Review (SAGE), and Elementa: Science of the Anthropocene (University of California Press). The term is also profusely used in scientific books and articles without quotation marks, as if it was already formalized. The same is true in a wide array of disciplines apart from natural sciences, where the 'Anthropocene' is used for a variety of purposes beyond its genuine stratigraphic meaning. For example, in philosophical, political, and economic terms, the 'Anthropocene' has been considered an expression of modernity, an attack to the Earth System or a dystopian end of humanity, an assault to human rights, an outgrowth of capitalism, an excess of consumerism, the definitive decoupling between human welfare and environmental impacts, or an ethical and biological imperative, among others [29].

The author is not fully aware of the different 'Anthropocene' meanings used in non-scientific disciplines, but, recently, he has a very illustrative experience in this sense in a seminar celebrated in the Autonomous University of Madrid (Spain), where he was invited to give a talk on the scientific bases of the 'Anthropocene'. The audience was composed mainly of philosophers, sociologists, anthropologists, historians, politicians, ecological activists, poets, and artists, as well as some scientists unfamiliar with geology and earth sciences, in general. The feedback received from this public may be summarized into three main points. One of the participants commented that it does not matter whether geologists officially formalize or not the 'Anthropocene' as a new epoch, the term will keep being used. Another 
member of the audience wondered about what is the interest of a number of geologists in defining a new stratigraphic unit and what could this be useful for. Another participant asked why not using a different term, devoid of any stratigraphic connotation, as, for example, the Great Acceleration, simply to describe a new historical phase in the human-Earth relationships. These are recurrent and unsolved scientific questions that emerged from a mostly non-scientific but enlightened and open-minded audience, which suggests that these points are not trivial and are general enough to be seriously considered.

Regarding the first point, it seems clear that the preliminary definition by Crutzen and Stoermer [22] of the 'Anthropocene' as a new geological epoch, which is characterized by the human footprint on Earth, is enough in most non-scientific sectors (and also in scientific ones, especially in environmental sciences), where there is no concern about further ICS/IUGS scientific formalization. The second point, the interest of a number of scientists in formalizing the 'Anthropocene', seems to obey to the conviction that there is sufficient stratigraphic basis for it to be considered a new geological series/epoch. In addition, a number of geologists favor such formalization because they believe that the official recognition of human impact of Earth System could make the society and governments aware of such situation, which could facilitate preventive and corrective actions. For example, the formalization of the 'Anthropocene' has been considered to be useful to fully develop an international law of the sea [30]. The third point, that is, choosing a different name devoid of stratigraphic significance, i.e., without terminations such as '-cene', -zoic', or '-gene', has also been proposed in the scientific literature, but this option is rarely considered [21].

\section{Does Formalization Matter?}

It seems clear that formalization only matters for a number of geologists, particularly stratigraphers. For non-geologists, formalization seems not to be relevant and the term is freely used, commonly without quotation marks, with a variety of meanings, mostly with evident environmental and historical connotations. Therefore, it seems that the formalization or not of the 'Anthropocene' is irrelevant for most scientific and non-scientific sectors, and the term will probably remain in the quotidian life with a diffuse meaning, depending on the preferences of each particular user [11]. But, scientific questions should be addressed using rigorous scientific methods, rather than wide consensus involving scientific and non-scientific sectors. In the case of the 'Anthropocene', the discipline that matters is stratigraphy, not environmental or historical sciences, and the issue is in the hands of the AWG and the ICS/IUGS, whose final decision should be universally accepted and implemented.

If the 'Anthropocene' is finally formalized, then the Holocene will be terminated and a new epoch will have started. However, if it is not formalized, the term should be abandoned. There are numerous alternative terms, without stratigraphic meaning, which could be used to express the human footprint on Earth System. It would be illustrative to compare this situation with the hypothetical case of an eventual proposal for a new element of the periodic table whose formalization corresponds to the International Unions of Pure and Applied Physics and Chemistry (IUPAP/IUPAC). It could be asked whether non-chemical/physical scientists and non-scientists would be as careless as they are in the case of the 'Anthropocene' and how could they behave if the IUPAP/IUPAC finally decided that the new 'element' proposed did not qualify as a new component of the periodic table. Certainly, the term and concept would be abandoned. A similar example could be found in language if a word is not accepted by the corresponding academy as a valid term to be included in the dictionary. Why should the case be different with the 'Anthropocene'? Martin Head [19] and Jan Zalasiewicz [22] question the above physical/chemical analogy arguing that the nature of the elements of the periodic table is different from the nature of the units of the ICC — the same could be said for the words of a dictionary-but the comparison is not about these fundamental units per se but on the need for formalization rules and organisms and also on the attitude of scientific and non-scientific sectors regarding such formalization.

From an environmental perspective, the issue of the human influence in the Earth's System and the actions needed to redress the situation will not change whether the term 'Anthropocene' is formalized 
or not. The 'Anthropocene' is strictly a stratigraphic term and the issue of its formalization as a new chronostratigraphic unit should be disentangled from any environmental, philosophical, sociological, political, or economic considerations [31]. Obviously, the 'Anthropocene' term and concept have implicit environmental connotations that cannot be ignored, but this could not form the basis for the formalization of a new chronostratigraphic unit of the ICC. It will be interesting to follow the progress of the AWG proposal and the further discussions within the ICS and the IUGS, to realize whether or not we can freely use the term 'Anthropocene' without quotation marks or we should remove it from our dictionaries. Formalization matters, not only in physics, chemistry, or language, but also in geology.

\section{A Quaternary Special Issue}

A comprehensive analysis of the possible alternatives if the AWG proposal is finally rejected by the ICS/IUGS cannot be performed in a single paper and by a single author. This editorial paper should be considered as an introduction that is aimed at encouraging interested scholars to contribute to the special issue that our journal has just launched on the topic (https:/ / www.mdpi.com/journal/ quaternary/special_issues/anthropocene_formalization). Contributions from any field of knowledge are welcome, provided they fit within the topic of the 'Anthropocene' formalization, with emphasis on the possible consequences of an unsuccessful outcome and the available alternatives. Submissions from authors who do not care about formalization are also welcome if they provide sound arguments in support to their points of view. Ideally, the special issue should be a sample of the diverse positions on the subject from any specialty. If this objective is accomplished, then a final editorial synthesis may be considered.

Acknowledgments: The author is very grateful to Lucy Edwards, Erle Ellis, Philip Gibbard, Martin Head and Jan Zalasiewicz for sharing their views on the 'Anthropocene' formalization, as well as for providing useful feedback on different versions of the manuscript.

Conflicts of Interest: The author declares no conflict of interest.

\section{References}

1. Monastersky, R. Anthropocene: The human age. Nature 2015, 519, 144-147. [CrossRef] [PubMed]

2. Salvador, A. International Stratigraphic Guide. A Guide to Stratigraphic Classification, Terminology, and Procedure; Geological Society of America: Boulder, CO, USA, 1994; 214p.

3. Waters, C.M.; Zalasiewicz, J.; Summerhayes, C.P.; Fairchild, I.J.; Rose, N.L.; Loader, N.J.; Shotyk, W.; Cearreta, A.; Head, M.J.; Syvitski, J.P.M.; et al. Global Boundary Stratotype Section and Point (GGSP) for the Anthropocene Series: where and how to look for potential candidates. Earth-Sci. Rev. 2018, 178, 379-429. [CrossRef]

4. Zalasiewicz, J.; Waters, C.N.; Summerhayes, C.P.; Wolfe, A.P.; Barnosky, A.D.; Cearreta, A.; Crutzen, P.; Ellis, E.; Fairchild, I.J.; Gałuszka, A.; et al. The Working Group on the Anthropocene: Summary of evidence and interim recommendations. Athropocene 2017, 19, 55-60. [CrossRef]

5. Zalasiewicz, J. (University of Leicester, Leicester, UK). Personal communication, 27 September 2018.

6. Finney, S.C. The 'Anthropocene' as a ratified unit of the ICS International Stratigraphic Chart: Fundamental issues that must be addressed by the Task Group. In A Stratigraphical Basis for the Anthropocene; Waters, C.N., Zalasiewicz, J.A., Williams, M., Ellis, M.A., Snelling, A.M., Eds.; The Geological Society of London: London, UK, 2014; pp. 23-28.

7. Gibbard, P.L.; Walker, M.J.C. The term 'Anthropocene' in the context of formal geological classification. In A Stratigraphical Basis for the Anthropocene; Waters, C.N., Zalasiewicz, J.A., Williams, M., Ellis, M.A., Snelling, A.M., Eds.; The Geological Society of London: London, UK, 2014; pp. 29-37.

8. Waters, C.N.; Zalasiewicz, J.A.; Williams, M.; Ellis, M.A.; Snelling, A.M. A Stratigraphical Basis for the Anthropocene; The Geological Society of London: London, UK, 2014; 321p. 
9. Waters, C.N.; Zalasiewicz, J.; Summerhayes, C.P.; Barnosky, A.D.; Poirier, C.; Gałuszka, A.; Cearreta, A.; Edgeworth, M.; Ellis, E.C.; et al. The Anthropocene is functionally and stratigraphically distinct from the Holocene. Science 2016, 351, aad2622. [CrossRef] [PubMed]

10. Finney, S.C.; Edwards, L.E. The "Anthropocene" epoch: Scientific decision or political statement? GSA Today 2015, 26, 4-10. [CrossRef]

11. Edwards, L.E. What is the Anthropocene? EOS 2015, 96, 6-7. [CrossRef]

12. Autin, W.J.; Holbrook, J.M. Is the Anthropocene an issue of stratigraphy or pop culture? GSA Today 2012, 22, 60-61. [CrossRef]

13. Zalasiewicz, J.; Waters, C.N.; Wolfe, A.P.; Barnosky, A.D.; Cearreta, A.; Edgeworth, M.; Ellis, E.C.; Fairchild, I.; Gradstein, F.M.; Grinevald, J.; et al. Finney and Edwrads article. GSA Today 2016, 27, e36-e37.

14. Zalasiewicz, J.; Waters, C.N.; Wolfe, A.P.; Barnosky, A.D.; Cearreta, A.; Edgeworth, M.; Ellis, E.C.; Fairchild, I.J.; Gradstein, F.M.; Grinevald, J.; et al. Making the case for a formal Anthropocene Epoch: An analysis of the ongoing critiques. Newsl. Stratigr. 2017, 50, 205-226. [CrossRef]

15. Ruddiman, W.F. The Anthropocene. Ann. Rev. Earth Planet. Sci. 2013, 41, 45-68. [CrossRef]

16. Lewis, S.L.; Maslin, M.A. Defining the Anthropocene. Nature 2015, 519, 171-180. [CrossRef] [PubMed]

17. Ellis, E.; Maslin, M.; Boivin, N.; Bauer, A. Involve social scientists in defining the Anthropocene. Nature 2016, 540, 192-193. [CrossRef]

18. Ellis, E. (University of Maryland-Baltimore County, Baltimore, MD, USA). Personal Communication, 12 October 2018.

19. Zalasiewicz, J. (University of Leicester, Leicester, UK). Personal communication, 16 October 2018.

20. Gibbard, P. (University of Cambridge, Cambridge, UK). Personal communication, 23 September 2018.

21. Rull, V. The Humanized Earth System (HES). Holocene 2016, 26, 1513-1515. [CrossRef]

22. Head, M. (Brock University, St. Catharines, ON, Canada). Personal communication, 9 October 2018.

23. Williams, M.; Zalasiewicz, J.; Haff, P.K.; Schwägerl, C.; Barnosky, A.D.; Ellis, E.C. The Anthropocene biosphere. Anthr. Rev. 2015, 2, 196-219. [CrossRef]

24. Rull, V. The 'Anthropocene': A requiem for the geologic Time Scale? Quat. Geochronol. 2016, 36, 76-77. [CrossRef]

25. Stoppani, A. Corso di Geologia. Vol. II: Geologia Stratigrafica; G. Bernardoni e G. Brigola Editori: Milano, Italy, $1873 ; 868$ p.

26. Edwards, L. (US Geological Survey, Reston, VA, USA). Personal communication, 11 October 2018.

27. Ruddiman, W.F.; Ellis, E.C.; Kaplan, J.O.; Fuller, D.Q. Defining the epoch in which we live. Is a formally designated Anthropocene a good idea? Science 2015, 348, 38-39. [CrossRef] [PubMed]

28. Crutzen, P.J.; Stoermer, E.F. The 'Anthropocene'. IGBP Newsl. 2000, 41, 17-18.

29. Autin, W.J. Multiple dichotomies of the Anthropocene. Anthropocene Rev. 2016, 3, 218-230. [CrossRef]

30. Vidas, D. The Anthropocene and the international law of the sea. Philos. Trans. R. Soc. A 2011, 369, 909-925. [CrossRef] [PubMed]

31. Rull, V. A futurist perspective on the Anthropocene. Holocene 2013, 23, 1198-1201. [CrossRef]

(C) 2018 by the author. Licensee MDPI, Basel, Switzerland. This article is an open access article distributed under the terms and conditions of the Creative Commons Attribution (CC BY) license (http://creativecommons.org/licenses/by/4.0/). 